DOI: https://doi.org/10.32839/2304-5809/2020-12-88-49

УДК 316.130 .37

Воропаєва T.C. ${ }^{1}$

Київський національний університет імені Тараса Шевченка

\title{
ТРАНСФОРМАЦІЇ КОЛЕКТИВНОЇ ІДЕНТИЧНОСТІ ГРОМАДЯН УКРАЇНИ: ІНТЕГРАТИВНИЙ АНАЛІЗ
}

Анотація. У сучасному світі зростає інтерес до проблеми формування колективної ідентичності. Стаття
присвячена вивченню теоретичних, емпіричних і практичних аспектів трансформації колективної іден-
тичності в контексті інтегральної ідентології (це новий науковий напрям, який досліджуе різні фрорми
ідентичності колективних та індивідуальних субектів, динаміку їх розвитку і трансформацій з урахуван-
ням теоретичних, емпіричних та практичних аспектів). Інтегративний підхід дозволяє розглядати різні
форми колективної ідентичності (релігійну, регіональну, етнічну, національну, цивілізаційну тощо) в їх
системній едності як цілісну конфігурацію. Інтегративний аналіз дозволив вивчити динаміку трансфор-
мацій різних форм колективної ідентичності громадян України у пострадянський період. За цей період
відбулися кардинальні зміни у багатьох сферах суспільного життя України. Помаранчева Революція,
Революція Гідності, анексія Криму, війна на Донбасі призвели до значних політичних, правових, соціаль-
но-економічних та соціокультурних змін, що спричинили процеси трансформації релігійної, регіональної,
національно-культурної, громадянсько-політичної, цивілізаційної ідентичності громадян України.

Ключові слова: ідентичність, інтегральна ідентологія, колективна ідентичність, міждержавний збройний конфлікт, громадяни України.

Voropayeva Tetiana

Taras Shevchenko National University of Kyiv

\section{TRANSFORMATIONS OF COLLECTIVE IDENTITY OF CITIZENS OF UKRAINE: INTEGRATIVE ANALYSIS}

Summary. In the modern world, there is a growing interest in the problem of forming a collective identity. The category of «identity», despite the diversity of theoretical and empirical research, is still one of the most complicated. The article is devoted to the study of theoretical, empirical and practical aspects transformations of the collective identity in the context of integral identology (this is a new scientific direction, which explores various forms of identity of collective and individual actors, the dynamics of their development and transformation, taking into account theoretical, empirical and practical aspects). The aim of this article is to study the dynamics of the changes in the collective identity of Ukrainian citizens from 1991 to 2020 through the prism of the integrative approach. The integrative approach allows us to consider various forms of collective identity (religious, regional, ethnic, national, civilizational, etc.) in their systemic unity as an integral configuration. The integrative analysis allowed us to study the dynamics of transformations of various forms of collective identity of Ukrainian citizens from 1991 to 2020 . During post-Soviet period there have been radical changes in many spheres of public life of Ukraine. The Orange Revolution, the Revolution of Dignity, the annexation of the Crimea, the war on the Donbas led to significant political, legal, socio-economic and socio-cultural changes that caused to the processes of transformation of religious, regional, national-cultural, civic-political, civilizational identity of Ukrainian citizens. Integrative approach allowed us to define the armed conflict on the territory of Ukraine as a Russian-Ukrainian inter-state armed conflict of a neocolonial type. Under the effect of Russian-Ukrainian inter-state armed conflict of a neocolonial type is the constructive transformation of political and legal culture citizens of Ukraine. One important consequence of this process is the Ukrainian political nation formation and becoming of positive national-cultural, and civic-political and European civilizational identity.

Keywords: identity, integral identology, collective identity, inter-state armed conflict, citizens of Ukraine.

Постановка проблеми. Актуальність інтегративних досліджень, присвячених ідентифікаційній проблематиці, зумовлюеться тим величезним значенням, яке вони мають у житті нових незалежних держав, що сформувалися у постколоніальний період на пострадянському просторі. Проблема трансформаціі колективної ідентичності громадян України має сьогодні практичну актуальність для України, іiі важливість підвищуеться в умовах тимчасової окупації українських територій та військової агресії Російської Федерації проти України. На жаль, інтегративне осмислення динаміки трансформацій колективної ідентичності громадян України не дістало належного розвитку в науко- вих дослідженнях. Тому ми започаткували новий науковий напрям - інтегральну ідентологію, у рамках якої на основі інтегративного (трансдисциплінарного) аналізу теоретичних, емпіричних і практичних аспектів проблеми досліджуються різні форми ідентичності колективних та індивідуальних суб'єктів, динаміка їхнього розвитку й трансформацій з урахуванням різнопланових чинників, що зумовлюють становлення і розвиток певної форми ідентичності. Інтегральна ідентологія передбачає розгляд об'єкта дослідження у його зв'язках і взаємозалежностях 3 іншими процесами та явищами.

Аналіз останніх досліджень і публікацій. Феномен ідентичності людини давно привертає

${ }^{1}$ ORCID: https://orcid.org/0000-0001-8388-7169

(C) Воропаєва Т.С., 2020 
увагу представників багатьох соціальніх та гуманітарних наук, кожна 3 яких робить свій внесок в обговорення і вирішення даної проблеми. У фpiлософії проблема ідентичності розроблялась, починаючи з окремих роздумів Аристотеля, і продовжуючись у працях Джона Лока, Девіда Юма, Фрідріха Вільгельма Йозеда фон Шеллінга, Георга Вільгельма Фрідріха Гегеля та інших мислителів. Їхні наступники досліджували зв'язок між поняттями «ідентичність, «тотожність», «Я», «самість», «самосвідомість», структуру й критерії різних форм ідентичності, особливості взаємодії Я - Інший.

Американський психолог і фрілософр Вільям Джеймс наголосив на таких властивостях ідентичності, як боротьба свого і чужого, тотожність і відповідність собі й суспільству [6, с. 105]. Перші концепщії ідентичності були представлені в працях Зігмунда Фройда, Еріка Хомбургера Еріксона, Генрі Теджорела, Джона Тернера та інших вчених. Зокрема, міркування Зігмунда Фройда про ідентифікацію людей в масі, а також перше використання терміну «ідентифікація» були зафріксовані у його книзі «Масова психологія і аналіз людського Я» (1925), яка була написана ще у 1921 р. [11, с. 24-36]. Пізніше його думки стали фундаментом для сучасного розуміння як індивідуальної, так і колективної ідентичності. Французький фрілософр Поль Рікер (Paul Ricœur) та один з основоположників інтеракціонізму Джордж Герберт Мід (George Herbert Mead) пояснюють у своїх дослідженнях поняття ідентичності через категорію «самість» [8; 10]. Американський психолог Ерік Хомбургер Еріксон увів поняття «ідентичність» в широкий науковий контекст і суттево популяризував його. Ще у 1940-1950-х роках він почав досліджувати етнічну ідентичність, звернувши увагу на історичну обумовленість формування та еволюції будь-якої ідентичності [16, с. 52]. Еріксон розглядав ідентичність людини як процесуальне явище, зв'язавши етапи формування ідентичності 3 життевими кризами, які відокремлюють один етап життевого циклу людини від іншого. Французький вчений Серж Московічі запропонував поняття «ідентифрікаційна матриця», у «клітинах» якої розміщуеться певна сукупність базових та периферійних ідентичностей індивіда [9, с. 3].

Належність до тіеї чи іншої етнічної спільноти сьогодні вивчається, як правило, з позицій двох концепцій: теорії соціальної ідентичності Генрі Теджоела, Джона Тернера і моделі двох вимірів ідентичності Джона Беррі. Теджоел і Тернер висувають загальний принцип, згідно з яким групова ідентифікація нерозривно пов'язана 3 диференціацією. Соціальна ідентичність у широкому розумінні являє собою результат процесу порівняння своєї групи 3 іншими соціальними об’єктами; у пошуках позитивної соціальної ідентичності індивід або група прагнуть самовизначитися, відособитись від інших, утвердити свою автономність [22, с. 7-24]. Відповідно до теорії акультурації Беррі, члени груп можуть демонструвати чотири типи установок у груповий взаємодії: на інтеграцію, асиміляцію, сепарацію і маргіналізацію. Джоном Беррі була запропонована модель двох вимірів етнічної ідентичності. Вона включає чотири типи етнічної ідентичності:
1) моноетнічна ідентичність, що збігається з офіційною етнічною приналежністю; 2) моноетнічна ідентичність 3 чужою етнічною групою, 3) біетнічна ідентичність, 4) маргінальна ідентичність [13, с. $139-140 ; 14$, с. 44-62].

Нові підходи до вивчення ідентичності 3 різних теоретико-методологічних позищій репрезентували Ян Ассман [1], Мартін Барретт [2], Семюел Гантінгтон [17], Марко Сінірелла [15, с. 227-248], Ентоні Сміт [21, с. 55-76] та ін. Феномен колективної ідентичності одними 3 перших почали досліджувати італійські вчені А. Мелуччі [18, с. 329-348] і А. Піззорно [20, с. 355-373], пізніше до них приедналися П. Бергер, Т. Лукман [3] та інші вчені. Відомі українські та російські вчені (С. Андрусів, М. Воловикова, П. Гнатенко i В. Павленко, О. Гнатюк, Я. Грицак, К. Кислюк, М. Козловець, Т. Кузьо, М. Рябчук, С. Рижакова, Т. Рязанова, М. Степико та ін.) вивчали етнічну, релігійну, регіональну, громадянську і національну ідентичність, етнічну і національну самосвідомість.

Виділення невирішених раніше частин загальної проблеми. Наші перші теоретикоемпіричні дослідження колективної ідентичності громадян України, які ми розпочали у 1991 році, показали, що концепт «колективна ідентичність» охоплюе певне колективне «Ми» конкретної спільноти чи спільності (регіональної, релігійної, етнічної, національної, цивілізаційної і т.п.), а на цій основі виділяються різні форми колективної ідентичності (регіональна, релігійна, етнічна, національна, цивілізаційна та ін.). Було зроблено висновок про необхідність інтегративного осмислення поставленої проблеми i започаткування інтегральної ідентології [4, с. 7-12; 5, с. 12-17]. На той час існувало досить багато теоретичних розробок, які допомагали зробити належне теоретико-методологічне обірунтування наших досліджень.

Зокрема, у європейській фрілософіï родоначальником інтегративного підходу в науці вважається Іммануїл Кант, який висловив ідею цілісності природи людини, виділивши ієрархічні рівні її психіки. На початку XX століття в Німеччині почала формуватись фрілософрська антропологія, яка продовжила розвиток ідей Канта. У 1972 р. швейцарський фрілософ і психолог Жан Піаже писав про ситуації, коли необхідною ставала інтеграція понять і методів різних дисциплін, які були близькі за своєю структурою, методам і способам перевірки результатів [19, с. 154-171]. Індійський фрілософ Шрі Ауробіндо розробляв основи нової інтегральної фрілософїі та психології (але його праця "Integral Psychology: The Psychological System of Sri Aurobindo" була опублікована лише у 1986 році, вже після його смерті [7]). Італійський психолог Роберто Ассаджіолі розробляв у 1960-1970-х роках теоретичні основи психосинтезу - методу психотерапіï, саморозвитку та інтегрального навчання особистості. Він опублікував посібник 3 принципів і методів психосинтезу (Psychosynthesis. A Manual of Principles and Techniques, Hobbs, Dormann \& Company, New York, 1965). Основні положення його концепції були перекладені на російську мову і опубліковані в московському журналі «Урания» у 1991 р. Чеський та амери- 
канський психолог Станіслав Грофр, засновник трансперсональної фрілософрії та психології, також зробив помітний внесок у розвиток інтегративного підходу до розуміння людської психіки, що відображено у його працях: «Пригода самовідкриття: виміри свідомості та нові перспективи у психотерапії («The adventure of self-discovery: Dimensions of consciousness and new perspectives in Psychotherapy» (1988)), «Бурхливі пошуки Я: Посібник для особистісного зростання через трансорормаційну кризу» («The stormy search for the Self: A guide to personal growth through transformative crisis» (1990)). Прикметно, що у 1995 році Станіслав Грофр став профресором фракультету психології Каліфорнійського інституту інтегральних досліджень (California Institute of Integral Studies, Сан-Франциско, США), який був заснований ще у 1968 році американським фpiлософром і письменником Кеном Вілбером, який став основоположником інтегральної метатеорії, покликаної об’єднати в одну діалектичну цілість науки про світ і про людину, традиції східного містицизму і західного раціоналізму, зовнішній досвід і внутрішні психічні стани. Кен Вілбер, розвиваючи ідеї Іммануїла Канта, Франца Брентано, Вільгельма Дільтея і Карла Густава Юнга, створив цілісну картину еволющії людської свідомості і описав багаторівневий спектр психічної реальності у своїх працях: «Спектр свідомості» («The Spectrum of Consciousness» (1977)), «Вгору від Едему: трансперсональний погляд на еволюцію людини» («Up from Eden: A Transpersonal View of Human Evolution» (1981)), «Око в око: Пошуки нової парадигми» («Eуe to Eye: The Quest for the New Paradigm» (1983)). Ці та інші наукові праці стали основою для утвердження інтегративного підходу в сучасній наущі.

Відомо, що поняття «інтегральний» означає об'єднання в єдину складну модель методів i теорій, які довели свою коректність у певних контекстах, відкидаючи будь-який редукщіонізм. Саме Кен Вілбер розробив теоретичні й практичні положення інтегрального підходу, метою якого $є$ конструктивне об'єднання відкриттів, зроблених у різних сферах людської діяльності (психологія, соціологія, фрілософрія, містицизм i релігієзнавство, постмодерністські рухи, емпіричні науки, теорія систем тощо [23, с. 71-92]).

На основі перерахованих праць і наших теоретико-емпіричних досліджень ми започаткували інтегральну ідентологію - новий науковий напрям, у рамках якого досліджуються різні фрорми ідентичності колективних та індивідуальних суб’єктів, динаміка їхнього розвитку й трансформацій з урахуванням теоретичних, емпіричних та практичних аспектів. На жаль, інтегративне осмислення динаміки трансформацій колективної ідентичності громадян України не дістало належного розвитку в наукових дослідженнях. Це обумовило мету статті - вивчити динаміку трансформацій колективної ідентичності громадян України з 1991 по 2020 роки крізь призму інтегративного підходу.

Виклад основного матеріалу. Оскільки більшість сучасних дослідників вважають, що ідентичність $є$ результатом процесу ідентифрікації (яка розглядається як процес уподібнення, ототожнення себе або своєї референтної групи
3 ким-небудь або чим-небудь), то цей феномен необхідно розглядати як динамічну структуру, яка розвивається упродовж усього людського життя, причому ï розвиток $є$ нелінійним і нерівномірним, може розгортатися як у прогресивному, так і в регресивному напрямку, проходячи етапи подолання криз ідентичності. У ранні періоди життя ідентифікація із "значимими людьми» важлива для успішної інтеграції в соціум. Формування ідентичності передбачає здатність до емощійного резонансу 3 іншими людьми. Основна фоннкція ідентичності полягає у забезпеченні адаптації до нового соціального середовища, збереженні визначеності та щілісності особистості.

Сьогодні проблематика ідентичності представлена майже у всіх галузях суспільних та гуманітарних наук. Звичайно, ці дослідження не завжди узгоджені між собою через різні теоретико-методологічні засади. Це ускладнюе як теоретичні узагальнення, так і порівняння результатів емпіричних досліджень. Але все ж таки існує кілька теоретичних позищій, які є загальновизнаними для більшості сучасних дослідників ідентичності: а) включення поняття «ідентичність» в проблематику, пов'язану з формуванням мотиващіі, розвитком суб'єктності, засвоєнням цінностей; б) переміщення наукового інтересу дослідників від структурних характеристик ідентичності до процесуальних; в) констатація кризи ідентичності особистості в умовах «плинної» сучасності, що надає кожному індивіду безмежне поле вибору або ж провокуе на відмову від нього і втрату власної суб’єктності. Деякі дослідження індивідуальної та колективної ідентичності, які були проведені в останні роки, спрямовані на розуміння того, як саме людина протистоїть наростаючій невизначеності, множинності й мінливості оточуючого світу [5; 12$]$.

Таким чином, більшість науковців вважають, що ідентифрікація - це фрундаментальний процес самовизначення індивіда, а ідентичність - це результат цього процесу. Поняття «ідентичність» має інтегративний характер; воно об'єднує індивідуальні й соціальні начала. Ідентичність це феномен, який базуеться на діалектичному взаємозв'язку суспільства й індивіда та характеризує якість цього взаємозв'язку. Адже індивід стає учасником багатьох соціальних зв'язків і виконуе багато соціальних ролей, які відображаються в індивідуальній та колективній ідентичності. Всі форми соціальної ідентичності пов'язані із здатністю індивіда дати відповідь на запитання «Хто Я?» стосовно різних груп і спільнот. Оскільки індивід є одночасно членом багатьох груп, то у нього формуеться система ідентичностей, які відповідають різним сорерам його досвіду й діяльності (вікова, статева, сімейна, територіальна, етнічна, національна, релігійна, профресійна, субкультурна, континентальна та інші). Всі ці ідентичності вибудовуються у певну системну іерархію. Така іерархія є відносно стійким утворенням, яке може або відтворюватися у незмінному вигляді, або кардинально перебудовуватись. Всі ідентифікаційні перебудови i відтворення залежать від певних контекстів і ситуащій, а також від рішень і дій самого індивіда. У рамках ідентифікаційної іерархії є домінантні й субдомінантні ідентичності. Домінуюча 
ідентичність може обумовлювати специфіку iєрархізації, структуризації, субординації інших ідентичностей, а також детермінувати їхню взаємодію. Різноманітні потреби, уявлення, смаки, емоції, почуття, інтереси, принципи, переконання, естетичні й етичні пріоритети, мотиви, світогляд, цінності та смисли особистості впливають на структурування й переструктурування власної ієрархії ідентичностей.

Ідентифікащійні процеси можуть бути усвідомленими і неусвідомленими. Наприклад, дитина може неусвідомлено уподібнювати себе іншій значимій людині як певному зразку, це відбувається на основі емоційних зв'язків, емпатії тощо. На формування ідентифрікаційної системи дитини впливає цілий комплекс різноманітних чинників, 3 яких найважливішими $€$ контакти із «значущими іншими» (тобто із значущими людьми). У підлітковому та юнацькому віці провідний вплив на формування ідентифікаційної системи особистості починають відігравати ціннісно-смислові утворення вищого рівня.

Ідентичність $є$ не статичним, а динамічним утворенням. Ідентифікаційна система особистості фрормуеться тоді, коли їі різні компоненти починають фрункціонувати як єдиний механізм. Отже, ідентичність є системним, багатокомпонентним і багаторівневим утворенням людської психіки. Будь-яка нова ідентичність індивіда здатна «вбудуватись» в уже існуючу систему його ідентичностей. Між компонентами ціеї системи можуть бути або гармонійні, або дисгармонійні взаємозв'язки. Всі компоненти цієї системи мають безліч ступенів свободи, що ускладнюе можливість вивчення різних форм ідентичності. Саме тому не можна досліджувати кілька форм ідентичності у рамках $100 \%$ (наукові статті з такими результатами трапляються досить часто), оскільки кожна 3 них є важливою підсистемою, самостійний розвиток якої можливий у будьякому напрямку, зокрема, кожна ідентичність може зростати від найнижчого до найвищого рівня (від 0\% до 100\%). Отже, кожну фрорму ідентичності треба вивчати окремо, тоді можна порівнювати рівні розвитку різних форм ідентичності, а також визначити ідентичності, які є домінуючими в рамках системної ієрархії. Колективна ідентичність пов'язана 3 процесами прийняття індивідом певних групових уявлень, норм і цінностей, 3 його готовністю до подібного способу мислення, до вираження спільних почуттів, до колективних дій заради реалізації спільних інтересів. У кризові часи, в періоди політичної, економічної та соціальної нестабільності колективна ідентичність може стати основою для стійкої соціальної солідарності людей. Отже, ідентифікаційна система особистості є активним інтегруючим началом, яке відображає ㄲï співпричетність (а не тільки прив'язаність) до різних груп і спільнот, сприяє розгортанню суб'єктної саморегуляції та формуванню відповідної спрямованості власної діяльності. Ідентифікаційна система здатна узгоджувати у внутрішньому світі особистості різні смисли, цінності, переживання і ставлення до світу, зберігаючи автономність і автентичність особистості.

Таким чином, для наукового дослідження ідентичності (як системного, багатокомпонентно- го й багаторівневого утворення) найбільш оптимальним $е$ інтегративний підхід, який дозволяе вивчати різні види й типи ідентичності у їхній системній цілісності, а також врахувати свідомі й несвідомі аспекти ідентифікаційних процесів. Інтегративний підхід сприяе знаходженню методів, адекватних досліджуваному феномену, 3 урахуванням усіх особливостей та рівнів його розвитку. Методологічною основою інтегративного підходу є філософська ідея цілісності людини.

Концептуальним методологічним ядром нашого дослідження є інтегративний аналіз колективної ідентичності як складної, багаторівневої та багатокомпонентної системи. Дослідження базується на концептуальній позиції: будь-яка форма колективної ідентичності є системою, яка складається з окремих частин, пов'язаних певними відносинами; ця система знаходиться в процесі постійного розвитку та взаємодії 3 навколишнім середовищем. Зокрема, національна ідентичність складається 3 національно-культурної ідентичності (яка формуеться в рамках етнічної нації) і громадянсько-політичної ідентичності (яка формується в рамках політичної нації). Відповідно, европейська ідентичність складаеться 3 континентальної (географрічно мотивованої) та цивілізаційної ідентичності (ціннісно мотивованої). Окремі науковці вважають колективну ідентичність одновимірним об’єктом і вивчають всі їі різновиди у рамках $100 \%$. Насправді треба досліджувати кожну підсистему колективної ідентичністі окремо, а іерархію різних форм колективної ідентичності слід визначати за допомогою методу ранжування.

Процес формування колективної ідентичності громадян України досліджувався нами у 1991-2020 роках у ряді міжнародних дослідницьких проектів Центру українознавства Київського національного університету імені Тараса Шевченка («Українська національна ідея: теоретичні та емпіричні аспекти», Сощіально-психологічні та регіональні аспекти фрормування національної самосвідомості громадян України як чинника державотворення»; «Трансформація національної ідентичності: історіософрські, культурологічні та соціально-психологічні аспекти» та ін.), які були підтримані Фондом «Відродження», Фондом Фрідріха Еберта, Державним фондом фрундаментальних досліджень, а також Асоціацією українських банків. У цих проектах вивчалися релігійні, етнічні, метаетнічні, місцеві, регіональні, національні, европейські, планетарні, пострадянські та інші різновиди ідентичності українських громадян, що проживають в різних регіонах країни. Всього було досліджено 58100 респондентів від 18 до 89 років, (з них $48,5 \%$ - чоловіки, а 51,5\% - жінки).

Для вивчення трансформацій різних фрорм ідентичності ми використовували методику М. Куна - Т. Макпартленда «Хто Я?», адаптовану методику «Шкала вимірювання ідентичності» М. Сінірелли, адаптований «Опитувальник колективної ідентичності» (який розробили Р. Лухтанен і Дж. Крокер) та інші методи. Опитування проводилися в усіх областях України (у 2013-2020 роках на окупованих територіях України дослідження не проводилось) методом 
індивідуального інтерв'ю (face-to-face) за місцем проживання. Вибірка репрезентативна за основними соціально-демографічними показниками. Надійність і достовірність результатів проведеного дослідження забезпечувалася методологічним обгрунтуванням його вихідних позицій; використанням сукупності діагностичних методик, адекватних меті і завданням дослідження; об'єднанням кількісного i якісного аналізу емпіричних даних; використанням методів математичної статистики із залученням сучасних програм обробки даних, репрезентативністю вибірки. Статистична похибка не перевищуе 2,0\%. Обробка даних здійснювалася у додатку IBM SPSS Statistics 21.0. Для аналізу були використані: метод фракторного аналізу, кореляційний аналіз, розрахунок узгодженості шкал, показники описової статистики.

Найважливіші результати наших багаторічних досліджень колективної ідентичності громадян України є такими: 1) у 1991-1994 роках пострадянська ідентичність займала перші місця (з 1-го по 5-те), але їі відрив від інших форм колективної ідентичності стабільно зменшувався; 2) протягом 1994-2004 рр. значимість пострадянської ідентичності стрімко зменшувалася (хоча в групі етнічних росіян і російськомовних українців, які проживають на Півдні і Сході України, пострадянська ідентичність і сьогодні займає досить високі позиції, хоча вже не домінуе); 3) етнічна ідентичність поступово зростала у всіх групах (найбільш активне її зростання спостерігалося в групах росіян, українців, кримських татар, євреїв); 4) релігійна ідентичність почала стрімко зростати у другій половині 2001 року (після візиту Папи Римського Іоанна Павла II в Україну), а також наприкінці 2018 р. - у першій половині 2019 р. у зв'язку з утворенням Православної Церкви України, а починаючи з 2004-2005 рр., респонденти все частіше використовують ідентитети "християнин» і «християнка»; 5) планетарна (загальнолюдська) ідентичність за ці роки практично не змінилася; 6) европейська континентальна ідентичність спочатку займала передостанні місця у рейтингах ідентитетів, але, починаючи з 1998-1999 рр., ïi значимість почала зростати (особливо в групі етнічних українців, поляків, угорців, словаків, румунів, кримських татар); 7) найбільш стрімко зростає европейська цивілізаційна ідентичність у жителів великих міст; 8) національна (або громадянсько-політична) ідентичність була законсервована протягом 1991-1993 рр. у всіх групах, але у 1994-1995 рр. вона почала падати в групі етнічних росіян, білорусів, евреїв; поступове зростання ціеї форми ідентичності в групі етнічних українців і в деяких групах національних меншин (перш за все, в групі етнічних поляків, грузинів і кримських татар) простежується в 1997-1999 рр. і в 2004-2005 рр.; 9) престижність нащіональної (або громадянсько-політичної) ідентичності більш повільно зростає на Сході і Півдні України, на відміну від Півночі, Центру та Заходу України; 10) найбільш помітні трансформації характерні для етнічної і національної (або громадянсько-політичної) ідентичності, але розрив між цими формами ідентичності на Сході і Півдні набагато більший, ніж на Півночі,
Заході та в Центрі України; 11) до 2010 р. у етнічних українців на Півдні і Сході України спостерігалася тенденція до зростання европейської та національної ідентичності (в 2010-2013 рр. цей процес призупинився); 12) у етнічних українців, вірменів і молдаван, які проживають на Сході і Півдні України, більш виражені ностальгічні настрої щодо СРСР, але у цих же етнічних груп, які проживають на Півночі, в Центрі та на Заході України, на перше місце виходить бажання відчувати себе європейцями; 13) у 2004-2008 рр. стабілізувалися емпіричні показники етнічної ідентичності (як в групі етнічних українців, так і в групі національних меншин); 14) в групі національних меншин в 2006-2007 pp. зросло значення регіональної ідентичності (при грамотній регіональній політиці цей тип ідентичності міг би стати базовою підставою для зміцнення загальноукраїнської ідентичності, адже в розвинених країнах світу регіональна ідентичність розглядаеться як субнаціональна); 15) високий рівень національної ідентичності в 1991 р. мали $26 \%$ респондентів, у 2001 р. $-25 \%$, а в 2011 р. - тільки 21\% респондентів; низький рівень національної ідентичності в 1991 р. мали $18 \%$, в 2001 р. - $27 \%$, а в 2011 р. - 39\% респондентів, що свідчить про повну відсутність виваженої політики національної ідентичності в Україні; 16) національна і європейська ідентичність досягли найвищого рівня розвитку в 2004-2005 pp. (у 2005 р. високий рівень національної ідентичності мали $28 \%$ респондентів, а низький рівень національної ідентичності був лише у $22 \%$ респондентів, в цьому ж році високий рівень європейської ідентичності мали $37 \%$ респондентів, а низький рівень - 18\%); 17) стала помітною тенденція до збільшення показників европейської цивілізаційної ідентичності (як в групі етнічних українців, так і в групі національних меншин); европейська ідентичність до 2020 р. не втрачала своєї значущості для громадян України тому, що запит на европейськість є дуже сильним в українському суспільстві.

Наші дослідження виявили антиколоніальну й антиімперську мобілізацію громадян України, яка спостерігалась упродовж трьох револющій в Україні (Студентської револющії на граніті, Помаранчевої революції та Революції Гідності) [12]. У 2010-2012 роках у рамках проведених нами досліджень було зафіксовано «дрейфр» европейської та української національної ідентичності із Заходу на Схід, але після 2014 року цей процес значно прискорився. У 2002-2014 роках регіональна ідентичність мешканщів Півдня і Сходу України формувалась не як українська, а як неукраїнська, в результаті негативного інформаційно-психологічного впливу місцевих ЗМІ та місцевої влади регіональна ідентичність мешканщів цих регіонів ставала не субнаціональною, а наднаціональною.

У 2014-2020 роках під впливом російської агресії відбулось переосмислення й передрорматування окремих форм колективної ідентичності громадян України. Добровольчий та волонтерський рухи також суттево вплинули на процес трансформації колективної ідентичності. Проведені дослідження показали, що: а) на трансфрормацію колективної ідентичності громадян України впливають багато чинників (одним 3 найважливіших чинників 
є засоби масової інформації, які можуть за допомогою інорормащійної війни нівелювати й знишити будь-яку форму колективної ідентичності); б) українська національно-культурна ідентичність поступово поширюеться на Схід і Південь (2014-2020 рр.); в) динаміка зростання громадянсько-політичної ідентичності по відношенню до регіональної була вищою у 2014-2018 роках; г) респонденти щиро пишаються досягненнями українських громадян у спорті та мистецтві, вважаючи це утвердженням України; r) поступово зростає ціннісне (а не інструментальне) ставлення респондентів до України та самоповага громадян України до себе.

Отже, агресія РФ суттево підірвала радянські стереотипи про «дружбу народів». Пострадянська ностальгія громадян України поступово нівелюеться під впливом російських агресорів. Російська анексія Криму та російсько-український міждержавний збройний конфрлікт на Сході України здійснює потужниий вплив на формування європейської цивілізаційної та української національної ідентичності.

Висновки. Таким чином, інтегративний підхід дозволяе розглядати різні форми колективної ідентичності (релігійну, регіональну, етнічну, національну, цивілізаційну та ін.) у їхній системній єдності, як цілісну конфігурацію. Проведені теоретико-емпіричні дослідження показали, що в ідентифікаційній матриці громадян України багато років формуються різні форми колективної ідентичності. Чинниками, які найбільше вплинули на активізацію цих форм колективної ідентичності, стали: «Помаранчева революція 2004 р.», проведення в Україні фріналу «Свробачення» у 2005 р., проведення в Україні фріналу Свропейського чемпіонату з футболу в 2012 р., відмова уряду від запланованого на кінець листопада 2013 р. підписання Угоди про Асоціацію між Україною та ЄС, події Свромайдану і Революції Гідності, а також російсько-укра- їнський міждержавний збройний конфрлікт неоколоніального типу.

Упродовж 2013-2020 років відбулись кардинальні зрушення у багатьох сфрерах суспільного життя України. Революція Гідності, анексія Криму, війна на Донбасі призвели до значних політико-правових, соціально-економічних та соціокультурних змін, які обумовили процеси трансформації колективної ідентичності громадян України. Під впливом «Револющії Гідності» та російсько-українського міждержавного збройного кондрлікту відбувається конструктивна трансформація політичної та правової культури громадян України. Важливим наслідком цього процесу $е$ форорування української політичної нації та позитивної національно-культурної і громадянсько-політичної ідентичності. Континентальна європейська ідентичність громадян України поступово трансфрормуеться у цивілізаційну ідентичність.

Базові цінності українців почали «дрейфрувати» у напрямку європейських цінностей. Національна (громадянсько-політична) ідентичність забезпечуе більш активну участь громадян у житті суспільства та держави. Під впливом Революції Гідності та російсько-українського міждержавного збройного конфлікту більш активно формуеться українське громадянське суспільство. Необхідне фундаментальне переосмислення політики ідентичності в Україні. Адже утвердження національно-культурної, громадянсько-політичної та європейської цивілізаційної ідентичності громадян України є одним з найважливіших стратегічних завдань, необхідних для подальшого виживання й розвитку України як незалежної держави. Упродовж 2014-2020 років в Україні відбулися якісні зміни, що можуть привести до встановлення ефективного громадського контролю над владою, забезпечення сталого розвитку суспільства, демократичної модернізації та європеїзації держави.

\section{Список літератури:}

1. Ассман Я. Культурная память: Письмо и память о прошлом и политическая идентичность в высоких культурах древности. Москва : Языки славянской культуры, 2004. 368 с.

2. Барретт М., Рязанова Т., Воловикова М. Развитие национальной, этнолингвистической и религиозной идентичности у детей и подростков. Москва : Издательство Института психологии РАН, 2001. 196 с.

3. Бергер П., Лукман Т. Социальное конструирование реальности. Трактат по социологии знания. Москва : «Медиум», 1995. 323 с.

4. Воропаева Т.С. Идентификация как психологический механизм формирования этнического самосознания. Мир психологии и психология в мире. Москва, 1995. № 1. С. 7-12.

5. Воропаєва Т. Трансформація національної ідентичності громадян України (1991-2001 рр.). Вісник КНУ імені Тараса Шевченка. Серія "Українознавство». 2002. Вип. 6. С. 12-17.

6. Джеймс Уильям. Личность. Психология личности : тексты. Москва : Изд-во МГУ, 1982. 288 с.

7. Костюченко В.С. Интегральная веданта: критический анализ фбилособбии Ауробиндо Гхоша. Москва : Наука, 1970. 189 с.

8. Мид Д. Интернализованные другие и самость. Алериканская социологическая мысль. Москва : Изд-во МГУ, 1994. $496 \mathrm{c.}$

9. Московичи С. Социальные представления: исторический взгляд. Психологический журнал. 1995. Т. 15 . № 1. С. 3-19.

10. Рикер П. Я-сам как другой. Москва : Изд-во гуманитарной литературы, 2008. 416 с.

11. Фрейд З. Психология масс и анализ человеческого «Я». Москва, 1925. 98 с.

12. Averianova Nina, Voropaieva Tetiana. Transformation of the Collective Identity of Ukrainian Citizens After the Revolution of Dignity (2014-2019). Kyiv-Mohyla Humanities Journal. 2020. No. 7. P. 45-71.

13. Berry J.W. Acculturation and psychological adaptation: review. Journeys into cross-cultural psychology: Selected papers from the 11th International conference of the International association for cross-cultural psychology held in Liege. Belgium : Swets \& Zeitlinger, 1994. P. 129-141.

14. Berry J.W., Poortinga Y.H., Segall M.H., Dasen, P.R. Cross-cultural psychology: Research and applications. Cambridge : Cambridge University Press, 1992. P. 44-62.

15. Cinnirella M. Exploring temporal aspects of social identity: the concept of possible social identities. European Journal of Social Psychology. 1998. No. 28.2. P. 227-248. 
16. Erikson Erik H. Identity and the Life Cycle. Selected Papers. New York : International Universities Press, 1959.171 p.

17. Huntington S.P. The Clash of Civilizations and the Remaking of World Order. New York : Simon and Schuster, 1996. $367 \mathrm{p}$.

18. Melucci A. Getting Involved: Identity and Mobilization in Social Movements. International Social Movement Research. 1988. P. 329-348.

19. Piaget Jean. L'epistemologie des Relations Interdisciplinaires. L’interdisciplinarite: problemes d'enseignement et de recherche dans les universites. Paris : OCDE, 1972. P. 154-171.

20. Pizzorno A. Some Other Kind of 'otherness': A critique of Rational Choice Theories. Development, Democracy and the Art of Trespassing. Notre Dame : University of Notre Dame Press, 1986. P. 355-373.

21. Smith A. National Identity and the Idea of European Unity. International Affairs. 1992. No. 68. P. $55-76$.

22. Tajfel H., Turner J.C. The social identity theory of intergroup behavior. Psychology of intergroup relations. Chicago : Nelson-Hall, 1986. P. 7-24.

23. Wilber Ken. An Integral Theory of Consciousness. Journal of Consciousness Studies. 1997. No. 4.1. P. 71-92.

\section{References:}

1. Assman Y.A. (2004) Kulturnaya pamyat: Pismo i pamyat o proshlom i politicheskaya identichnost $v$ vysokikh kulturakh drevnosti [Cultural Memory: Writing and memory of the past and political identity in the high cultures of antiquity]. Moscow: Yazyki slavyanskoy kultury, 368 p. (in Russian)

2. Barrett M., Ryazanova T., Volovikova M. (2001) Razvitiye natsionalnoy, etnolingvisticheskoy $i$ religioznoy identichnosti u detey $i$ podrostkov [Development of national, ethnolinguistic and religious identity in children and adolescents]. Moscow: Izdatelstvo Instituta psikhologii RAN, 196 p. (in Russian)

3. Berger P., Lukman T. (1995) Sotsialnoye konstruirovaniye realnosti. Traktat po sotsiologii znaniya [Social construction of reality. Treatise on the Sociology of Knowledge]. Moscow: «Medium», 323 p. (in Russian).

4. Voropayeva T.S. (1995). Identifikatsiya kak psikhologicheskiy mekhanizm formirovaniya etnicheskogo samosoznaniya [Identification as a psychological mechanism for the formation of ethnic self-awareness]. Mir psikhologii i psikhologiya v mire, no. 1, pp. 7-12. (in Russian)

5. Voropayeva T. (2002) Transformatsiya natsionalnoyi identychnosti hromadyan Ukrayiny (1991-2001 rr.) [Transformation of the national identity of the citizens of Ukraine (1991-2001)]. Visnyk KNU imeni Tarasa Shevchenka. Seriya "Ukrayinoznavstvo", vol. 6, pp. 12-17. (in Ukrainian)

6. Dzheyms Uilyam (1982) Lichnost [Personality]. Psikhologiya lichnosti: teksty. Moscow: Izd-vo MGU, 288 p. (in Russian)

7. Kostyuchenko V.S. (1970) Integralnaya vedanta: kriticheskiy analiz filosofii Aurobindo Gkhosha [Integral Vedanta: A critical analysis of the philosophy of Aurobindo Ghosh]. Moscow: Nauka, 189 p. (in Russian)

8. Mid D. (1994) Internalizovannyye drugiye i samost. Amerikanskaya sotsiologicheskaya mysl [Internalized others and self]. Moscow: Izd-vo MGU, 496 p. (in Russian)

9. Moskovichi S. (1995) Sotsialnyye predstavleniya: istoricheskiy viglyad [Social views: a historical perspective]. Psikhologicheskiy zhurnal, t. 15, no. 1, pp. 3-19. (in Russian)

10. Riker P. (2008) YA-sam kak drugoy [I am like another]. Moscow: Izd-vo gumanitarnoy literatury, 416 p. (in Russian)

11. Freyd Z. (1925) Psikhologiya mass i analiz chelovecheskogo "YA» [Psychology of the masses and analysis of the human «I»]. Moscow, 98 p. (in Russian)

12. Averianova Nina, Voropaieva Tetiana (2020) Transformation of the Collective Identity of Ukrainian Citizens After the Revolution of Dignity (2014-2019). Kyiv-Mohyla Humanities Journal, no. 7, pp. 45-71.

13. Berry J.W. (1994) Acculturation and psychological adaptation: review. Journeys into cross-cultural psychology: Selected papers from the 11th International conference of the International association for cross-cultural psychology held in Liege. Belgium: Swets \& Zeitlinger, pp. 129-141.

14. Berry J.W., Poortinga Y.H., Segall M.H., Dasen, P.R. (1992) Cross-cultural psychology: Research and applications. Cambridge: Cambridge University Press, pp. 44-62.

15. Cinnirella M. (1998) Exploring temporal aspects of social identity: the concept of possible social identities. European Journal of Social Psychology, no. 28.2, pp. 227-248.

16. Erikson Erik H. (1959) Identity and the Life Cycle. Selected Papers. New York: International Universities Press, 171 p.

17. Huntington S.P. (1996) The Clash of Civilizations and the Remaking of World Order. New York: Simon and Schuster, $367 \mathrm{p}$.

18. Melucci A. (1988) Getting Involved: Identity and Mobilization in Social Movements. International Social Movement Research, pp. 329-348.

19. Piaget Jean (1972) Lepistemologie des Relations Interdisciplinaires. Linterdisciplinarite: problemes denseignement et de recherche dans les universites. Paris: OCDE, pp. 154-171.

20. Pizzorno A. (1986) Some Other Kind of 'otherness: A critique of Rational Choice Theories. Development, Democracy and the Art of Trespassing. Notre Dame: University of Notre Dame Press, pp. 355-373.

21. Smith A. (1992) National Identity and the Idea of European Unity. International Affairs, no. 68, pp. 55-76.

22. Tajfel H., Turner J.C. (1986) The social identity theory of intergroup behavior. Psychology of intergroup relations. Chicago: Nelson-Hall, pp. 7-24.

23. Wilber Ken (1997) An Integral Theory of Consciousness. Journal of Consciousness Studies, no. 4.1, pp. 71-92. 